\title{
Distribution and habitat selection of early benthic stages of snow crab Chionoecetes opilio
}

\author{
Mélanie Dionne $^{1, *}$, Bernard Sainte-Marie ${ }^{2}$, Edwin Bourget ${ }^{3}$, Denis Gilbert ${ }^{2}$ \\ ${ }^{1}$ Département de Biologie, Université Laval Québec, Québec G1K 7P4, Canada \\ ${ }^{2}$ Maurice Lamontagne Institute, Fisheries and Oceans Canada, CP 1000, Mont-Joli, Québec, Québec G5H 3Z4, Canada \\ ${ }^{3}$ Université de Sherbrooke, Québec, Québec J1K 2R1, Canada
}

\begin{abstract}
Early benthic stages of the snow crab Chionoecetes opilio are presumed to be very stenothermic; they may be sensitive to environmental changes and thus affect subsequent adult population abundance. Little quantitative information exists on the habitat preferences of juvenile snow crabs to verify this. We determined the distribution pattern of juveniles in the NW Gulf of St. Lawrence, Canada, in May 2001. Temperature and substratum preferences were evaluated through controlled laboratory experiments in aquaria that had a temperature gradient and offered a choice of 3 sediment types (mud, sand and gravel). In general, early benthic stages displayed sharp size-/agedependent distributions and habitat preferences. In the field, juveniles from Instars I to IV were scarce in the core of the cold intermediate layer (CIL) but present immediately above and below this layer, where temperatures were $>0^{\circ} \mathrm{C}$. Older juveniles (Instars VI to VIII) were concentrated at depths $<27 \mathrm{~m}$ above the CIL. An analysis of historical data from 1989 to 2000 supported this depthdistribution pattern. Temperature preference in the laboratory shifted from a cold $\left(0.0\right.$ to $\left.1.5^{\circ} \mathrm{C}\right)$ to a warmer temperature range $\left(1.0\right.$ to $\left.4.5^{\circ} \mathrm{C}\right)$ between Instars III and V. Juveniles preferred mud in general. Early juvenile instars could represent the weakest link in the snow crab's life cycle because of their narrow habitat requirements.
\end{abstract}

KEY WORDS: Snow crab - Chionoecetes opilio - Habitat selection - Temperature preference · Distribution · Climate change

\section{INTRODUCTION}

High juvenile mortality is a widespread phenomenon among benthic marine invertebrates, and variability in juvenile survivorship can affect population size significantly (Gosselin \& Qian 1997, Hunt \& Scheibling 1997). Juveniles and adults are often spatially segregated, and different processes may regulate their survival (Gosselin \& Qian 1997). Abiotic habitat characteristics such as water temperature (Brown et al. 1992, Frederich et al. 2000) and substratum (Boudreau et al. 1990, Linnane et al. 2000) are known to affect settlement, distribution, growth and survival of many benthic decapod crustaceans. Relatively sudden changes in these environmental conditions may be more detrimental to juveniles than to adults, because the former are usually much less mobile.
The communities of the Gulf of St. Lawrence and the Labrador, Newfoundland and Scotian Shelves experienced a large change in the late 1980s, when cod Gadus morhua populations collapsed (e.g. Myers et al. 1996) while northern shrimp Pandalus borealis and snow crab Chionoecetes opilio populations increased rapidly (e.g. Sainte-Marie 1997, Lilly et al. 2000). This ecosystem shift followed a period of rapid cooling of the shelf waters in the NW Atlantic that started around the mid-1980s (Drinkwater 1996). Two hypotheses have been proposed to explain the increase in biomass of large decapod crustaceans. First, the increase has been attributed to indirect or direct climate effects, i.e. the extension of the availability of suitable habitat and/or greater survival of early juveniles in colder water. The second alternative or complementary hypothesis is that the collapse of cod (and of groundfish in 
general) relaxed a top-down predatory control (Tremblay 1997, Lilly et al. 2000, Worm \& Myers 2003). Testing these hypotheses is important for understanding marine ecosystem functioning, for gaining perspective into past climate-related events, and for predicting future events that might arise from climate changes (e.g. Frank et al. 1990). However, essential information on relationships between environmental conditions and juvenile crustaceans is missing or is incomplete.

The snow crab Chionoecetes opilio inhabits cold shelf or slope bottoms of the NW Atlantic and North Pacific (Slizkin 1982), and supports one of Canada's most important and most lucrative marine fisheries. The snow crab is also considered to be the most coldrestricted marine invertebrate resource of Canada (Foyle et al. 1989). Recruitment to snow crab populations in eastern Canada occurs annually from August to October, when megalopae settle on the bottom and metamorphose to Instar I (Lovrich et al. 1995). As in many other crustacean species (e.g. Stevens 2003), recently settled snow crabs are not very mobile and adopt a cryptic lifestyle (Lovrich et al. 1995). Intermoult periods last about 6 mo for Instars I to V, and $1 \mathrm{yr}$ for later instars. Snow crabs remain juvenile (sexually immature) until Instar VIII inclusive (Sainte-Marie et al. 1995, Alunno-Bruscia \& Sainte-Marie 1998).

The juvenile period is widely considered to be the most stenothermic of all snow crab life-history phases, but only fragmentary data are available to support this. Slizkin (1982) suggested that juveniles prefer temperatures $<0^{\circ} \mathrm{C}$ in the Bering Sea, while Brêthes et al. (1987) reported occurrences of juveniles at temperatures $<3^{\circ} \mathrm{C}$ in the NW Gulf of St. Lawrence. These 2 studies, however, considered all juvenile instars together and the distribution of the earliest instars was not examined. Some authors have suggested that Instar I crabs concentrate in the core of the cold intermediate layer (CIL) in the NW Gulf of St. Lawrence (Lovrich et al. 1995). If early juveniles are indeed more stenothermic than older juveniles and adults, they could be more vulnerable to climate changes than older individuals and could represent the weakest link in the snow crab life-cycle.

Although substratum type may affect snow crab distribution, little is known about its specific influence on early life stages. Early juveniles have been reported to prefer homogeneous mud substrata (Brêthes et al. 1987, Robichaud et al. 1989) or to be indifferent to sediment type (Conan et al. 1996). If snow crabs settle or survive only on specific substrata, then the persistence of populations could also depend on the spatial coincidence of adequate substratum and suitable temperature, as proposed by Rosenkranz et al. (2001) for tanner crabs Chionoecetes bairdi in Bristol Bay, Alaska.

We determined the distribution of juvenile snow crabs in the field, and conducted laboratory experiments to assess their habitat preferences. First, we predicted that spatial distribution of young juveniles would be heterogeneous in the wild. We then tested 2 models likely to explain the distribution pattern of juvenile snow crabs-temperature and substratum type - in the laboratory. We hypothesized that juvenile snow crabs would associate with the coldest water and the finest sediment available. This research is important for improving our knowledge on snow crab habitat-preferences, for understanding observed snow crab distributions, and for helping to understand the impact of climate change on those populations.

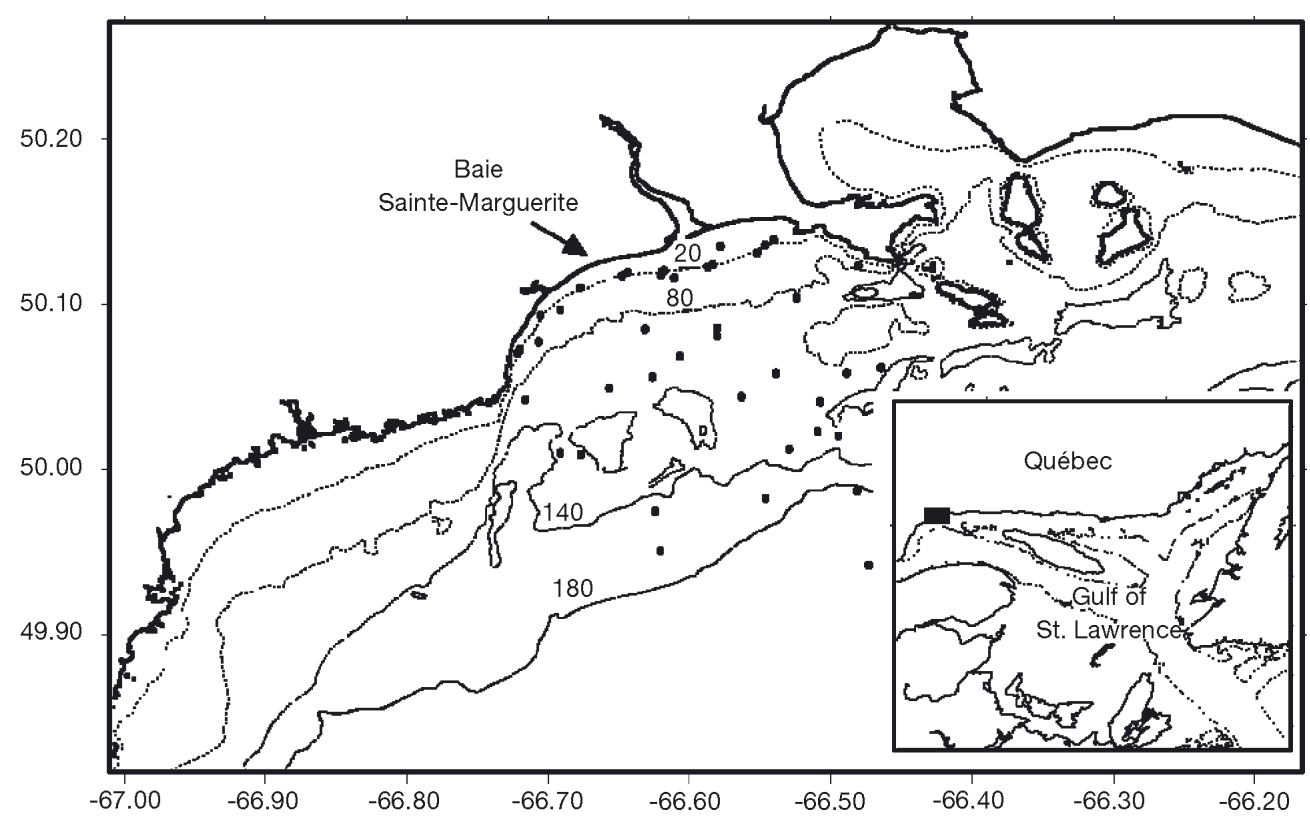

Fig. 1. Map of Baie SainteMarguerite and Gulf of St. Lawrence (inset) showing bottom depth (isobaths in metres) and locations $(\bullet)$ of beamtrawl samples in May 2001 


\section{MATERIALS AND METHODS}

Field distribution. The spatial distribution of snow crabs was studied in Baie Sainte-Marguerite (approximately $50^{\circ} 06^{\prime} \mathrm{N}, 66^{\circ} 35^{\prime} \mathrm{W}$ ) in the NW Gulf of St. Lawrence, eastern Canada (Fig. 1), in the first 3 wk of May 2001. (For site description see Sainte-Marie \& Hazel 1992.) We collected 5 to $10 \mathrm{crab}$ samples from randomly selected geographical positions in each of 6 discrete temperature-depth strata (see Fig. 2). The temperature-depth profile was determined from CTD profiles (SBE-19, Seabird Electronics) just before sampling. The mean temperature profile for our study area in late August 2000 (Fig. 2) was also determined, and represents the temperature conditions at the beginning of the settlement period and, by comparison with the spring profile, shows the extent of summer warming. Snow crabs were sampled with a $3 \mathrm{~m}$ wide beam trawl fitted with a $5 \mathrm{~mm}$ mesh net and heavy tickler chains to dislodge buried animals. Tows lasted approximately 2 to $5 \mathrm{~min}$ at $2.5 \mathrm{knots}$, and tow distance was determined from GPS readings for calculating area swept and crab density. Trawl content was sorted on board with a $2 \mathrm{~mm}$ sieve. Carapace width (CW) of crabs was measured with a vernier calliper to the nearest $0.1 \mathrm{~mm}$ (Fig. 3).

We attached 2 Vemco probes (8-bit Minilog TDR) to the upper frame of the trawl to record temperature and depth. A sediment sample was collected after each trawlset with a $0.04 \mathrm{~m}^{2}$ Shippek grab and was frozen for subsequent analysis. Homogeneity of the substratum along the towed distance was verified visually from recordings with a Sony Handycam video camera (VCL-0637H, ×0.6) fixed to the upper frame of the trawl between 2 halogen lights (20 W, $12 \mathrm{~V})$. Substratum appeared to be uniform over the distance of all individual trawlsets, suggesting that the sediment sample was representative of the whole sampled area. In the laboratory, sediment samples were thawed, dried and separated into fractions using $63 \mu \mathrm{m}$ to $32 \mathrm{~mm}$ sieves (phi $=4.0$ to -5.0 ) at $1 \mathrm{phi}$ intervals. Each fraction was then weighed and expressed as a percentage of the total weight of the sample.

Laboratory experiments. Juvenile crabs were collected with a beam trawl in Baie aux Outardes (approximately $48^{\circ} 58^{\prime} \mathrm{N}$, $\left.68^{\circ} 35^{\prime} \mathrm{W}\right)$ on the north shore of the St. Lawrence Estuary during August 2001. Crabs <15.5 mm (Instar V or younger) were selected. At that time of the year, Instars I and II are absent or scarce, there- fore they could not be used in laboratory experiments. Juvenile crabs were transferred to the Maurice Lamontagne Institute, where they were maintained in the dark in a tank with circulating seawater at $2^{\circ} \mathrm{C}$ and $28 \%$. They were fed twice weekly with thawed shrimp Pandalus borealis.

Habitat-preference experiments were conducted in aquaria containing 201 of seawater, which resulted in a water column $15 \mathrm{~cm}$ high. Each aquarium was inserted into a larger insulated tank containing $91 \mathrm{l}$ of non-toxic antifreeze mix regulated by a Johnson Control A-Y-D350 cooler system (Fig. 4). The large tank was covered by an insulated top, which blocked light. A heating coil was installed on the bottom of each aquarium at 1 randomly chosen side, and a Haake DC30 digital apparatus circulated warm freshwater through it. By varying the temperature of the cooling and heating coils, it was possible to generate different temperature gradients along the length of the aquarium. A sediment grid installed over the heating coil was separated along its length into 3 temperature zones, each subdivided into 3 longitudinal sections with an area of $7 \times 14 \mathrm{~cm}$ each, in which mud $(<0.5 \mathrm{~mm})$, sand ( 1 to $2 \mathrm{~mm}$ ) or gravel ( 2 to $16 \mathrm{~mm}$ ) was deposited in random order. A $4 \mathrm{~cm}$ wide border around the grid, also filled with these sediments, was provided to avoid wall interaction and to ensure independence of the data. Temperature probes (Dallas DS1820 $\pm 0.2^{\circ} \mathrm{C}$ )

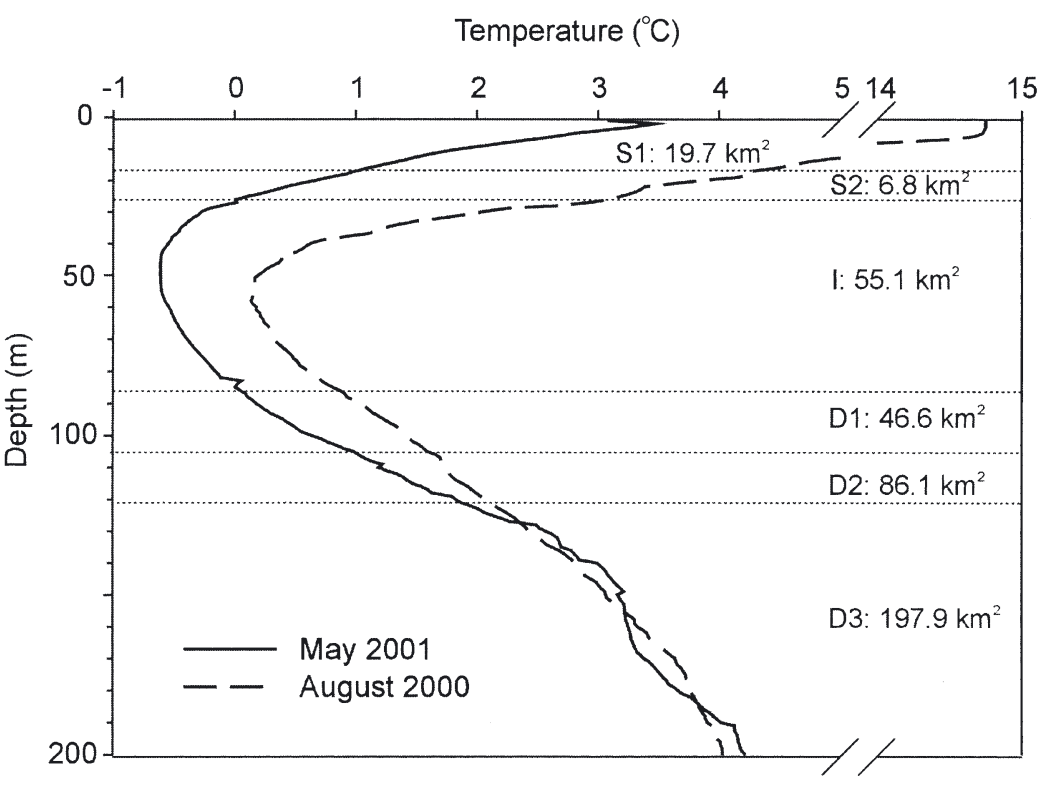

Fig. 2. Mean temperature profile in August 2000 ( $\mathrm{n}=2$ CTD casts) and May $2001(\mathrm{n}=50)$ as a function of depth in Baie Sainte-Marguerite. May profile is divided into 6 strata. $\mathrm{S} 1:>1{ }^{\circ} \mathrm{C},<18 \mathrm{~m}$ deep; $\mathrm{S} 2: 0$ to $1^{\circ} \mathrm{C}, 18$ to $27 \mathrm{~m}$; I: $<0^{\circ} \mathrm{C}, 27$ to $85 \mathrm{~m}_{i} \mathrm{D} 1: 0$ to $1^{\circ} \mathrm{C}, 85$ to $105 \mathrm{~m}_{\text {; }} \mathrm{D} 2: 1$ to $2^{\circ} \mathrm{C}, 105$ to $120 \mathrm{~m}_{\text {; }}$ D3: $>2^{\circ} \mathrm{C},>120 \mathrm{~m}$ (where $\mathrm{I}=$ core of cold intermediate layer). Estimated bottom area associated with each stratum is also shown 


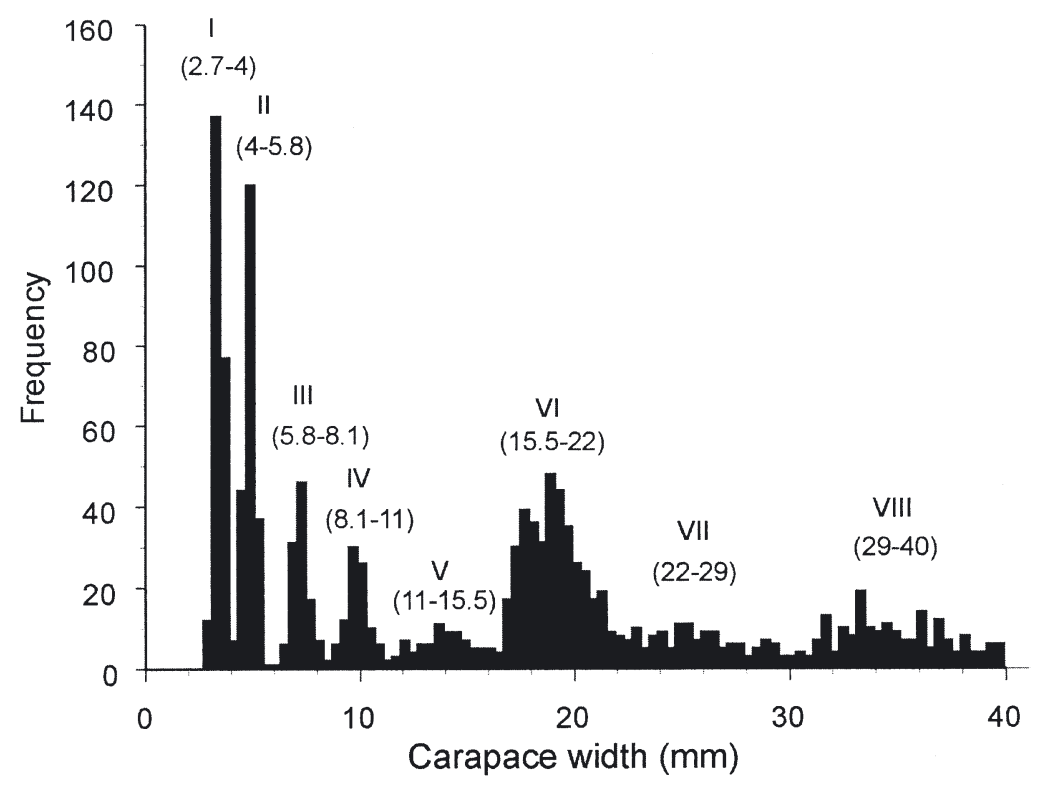

Fig. 3. Chionoecetes opilio. Size-frequency distribution of juveniles collected by beam trawl in Baie Sainte-Marguerite in May 2001. Roman numerals above modes indicate instars; numbers in parentheses represent range of carapace width (in $\mathrm{mm}$ ) for each instar. Instars I to II and Instars III to IV represent Cohorts I and II, respectively, and each subsequent instar represents a single cohort

were placed at the junction between temperature zones to record the temperature every $5 \mathrm{~min}$. The seawater in each aquarium was oxygenated to saturation and allowed to rest for $1 \mathrm{~h}$ before the start of an experiment to allow formation of a steady thermal gradient. Probes were used to confirm that water temperature was uniform across the width of the aquarium; 3 identical experimental tanks were used simultaneously.

Preliminary experiments conducted over $25 \mathrm{~h}$ with Instar III crabs allowed us to determine that 6 to $7 \mathrm{~h}$ were required for stability in crab distribution. In another preliminary experiment, oxygen depletion over time was measured every hour for $25 \mathrm{~h}$ with an oxygen metre (Orion 1230 Multimetre $\pm 1.5 \%$ ) in an aquarium containing 25 Instar $\mathrm{V}$ crabs. Oxygen concentration was $94 \%$ of the saturation value at the beginning of the experiment and dropped to $88 \%$ after $8 \mathrm{~h}$ and to $69 \%$ after $24 \mathrm{~h}$. Anomalous crab behaviours such as slower motions and overturning, presumably due to oxygen depletion (see also Tankersley \& Wieber 2000), were observed after $24 \mathrm{~h}$. Finally, to evaluate if juveniles had a gregarious behaviour that would influence the interpretation of distribution patterns, experiments with Instars II and $\mathrm{V}$ were conducted on mud only at a constant $2^{\circ} \mathrm{C}$ in 3 replicates, following the standard method (see next paragraph).

In the main experiments, cold, medium and warm zones ranged from 0 to 1,1 to 1.5 and 1.5 to $2.5^{\circ} \mathrm{C}$, respectively. We were unable to generate a gradient below $0^{\circ} \mathrm{C}$. Separate experiments were conducted for each of Instars III, IV and V, with 25 individuals deposited uniformly over the sediment grid at the beginning of the experiment. Based on the results of the preliminary experiments, the number of crabs in each sediment section was noted after $8 \mathrm{~h}$. Location of crabs was determined under red lighting, to which crustaceans are supposedly insensitive (Cronin 1986). Experiments were carried out with 3 (Instars III and IV) or 8 (Instar V) replicates. No crab was used more than once. After each replicate, the aquarium was emptied by gently siphoning the water, the sediment grid was extracted, and all components were thoroughly rinsed with seawater. We performed 2 additional experiments with modified thermal gradients to better resolve the temperature preference of Instar V crabs. In the first, cold, medium and warm zones ranged from 1.5 to $2.0,2.0$ to 3.0 and 3.0 to $4.5^{\circ} \mathrm{C}$, respectively; in the second, they ranged from 3.0 to $3.5,3.5$ to 4.5 and 4.5 to $5.5^{\circ} \mathrm{C}$, respectively. Both experiments were replicated 3 times.

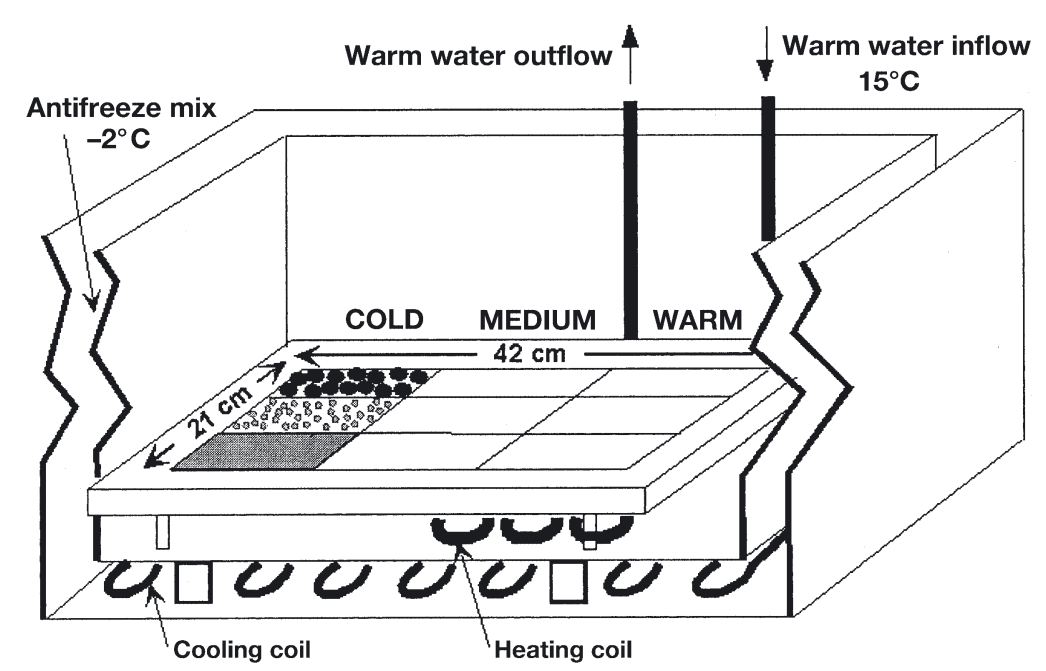

Fig. 4. Tank used in laboratory experiments, creating a horizontal thermal gradient. Each aquarium $(30 \times 50 \times 20 \mathrm{~cm})$ was inserted into a larger insulated tank $(60 \times 60 \times 60 \mathrm{~cm})$. (See description in 'Materials and methods') 
Statistical analysis. Homogeneity in the distribution of juvenile snow crabs among temperature-depth strata in the field was tested using a 1-factor ANOVA on crab density per trawlset. Instars I and II, and Instars III and IV, were combined for analyses because they belonged, respectively, to Cohorts I $\left(\right.$ Age $0^{+}$) and II (Age $1^{+}$) during the May sampling period, when moulting occurs (Sainte-Marie et al. 1995, Alunno-Bruscia \& Sainte-Marie 1998). Each of the other juvenile instars represented a distinct cohort. To meet the assumption of homoscedasticity, the surface (S1) and the deepest (D3) layers were excluded from the analyses of Instars I to VI.

To illustrate the field distribution of juveniles in relation to the availability of a habitat variable, a modelling analysis developed by Perry \& Smith (1994) was used. This analysis provides a perspective on juvenile use of the bottom that differs from the analysis of density patterns because it takes into account the bottom surface area associated with each temperature-depth stratum (see Fig. 2). This approach involved 3 steps. (1) The distribution of a habitat variable (temperature, depth) was characterized by an empirical cumulative distribution function $(\mathrm{CDF})$ : this represented the habitat conditions available in the sampled area and could be used to identify proportions of the habitat variable during the survey. (2) We constructed $1 \mathrm{CDF}$ per cohort to characterize the association between the number of crabs at a specific location and the habitat condition at that location (see Perry \& Smith 1994 for relevant equations); this illustrated the range of habitat conditions within which each cohort occurred. (3) To determine the strength of the association between the abundance of crabs and the habitat variable, the analysis compared the sampled CDF of the habitat variable to the CDF of each cohort. The test statistic represented the maximum absolute difference between both CDF curves and was then compared to a pseudo-population of similarly computed test statistics obtained by Monte-Carlo simulations, under the null hypothesis of no association between juvenile abundance and the habitat variable. Historical snow crab distribution-data for Baie Sainte-Marguerite (available for late April to late May of 1989 to 2000) were also compared with those for the year 2001. The earlier data were collected using the same beam trawl as described above, except that the net had a $15 \mathrm{~mm}$ mesh that severely undersamples Instars I and II (M.D. \& B.S.-M. unpubl. data), and the experimental design was also slightly different. For each year, at least 3 samples were randomly selected from each of 4 depth strata ( 0 to $20 \mathrm{~m}, 20$ to $80 \mathrm{~m}, 80$ to $140 \mathrm{~m}, 140$ to $200 \mathrm{~m})$. We used temperature and depth as habitat variables for the analyses for 2001, but only depth data were available for the 1989 to 2000 analysis.
To determine temperature and substratum preferences of juveniles in the laboratory, a 2-factor ANOVA on the number of crabs per grid section was used for each instar. To evaluate the degree of gregariousness of juvenile snow crabs, a nearest-neighbour analysis was carried out following the method of Clark \& Evans (1954). The distance between the centres of pairs of grid sections approximated the distance between individuals in separate sections; the distance between 2 individuals in the same section was taken to be 0 . This method tests the deviation of the observed distribution from a perfect random distribution with a statistic, $\mathrm{R}$, that varies from 0 to 2 ( $\mathrm{R}=0$ : perfectly clumped; $\mathrm{R}=1$ : randomly dispersed; $\mathrm{R}=2$ : uniformly dispersed).

Multiple pairwise-comparison tests using least-square means were performed for post-hoc comparisons after all ANOVAs, using the sequential Bonferroni test (Rice 1989). Data were $\log _{10}(x+1)$-transformed when assumptions of homoscedasticity and normality were not met. Homogeneity of variances was tested using Cochran's $C$-test, and normality of data was evaluated by examining plots of the residuals. ANOVA and post-hoc comparisons were conducted using the SAS software (SAS/STAT Version 8.2, SAS Institute).

\section{RESULTS}

\section{Field distribution}

The density of juveniles was not uniform among or within temperature-depth strata in May 2001 (Table 1). The highest or second-highest density of each cohort/instar was always recorded in the narrow S2 stratum $\left(0\right.$ to $\left.1^{\circ} \mathrm{C}\right)$, while density was always very low or null in Stratum I (representing the core of the CIL where temperatures were $<0^{\circ} \mathrm{C}$ ) and in the deepest stratum, D3. The density of juveniles within strata was highly variable, suggesting the existence of mesoscale aggregations (see also diving observations reported by Lovrich et al. 1995) and making statistical detection of any temperature or depth-distribution pattern difficult.

Nevertheless, ontogenetically coherent differences in crab-density patterns were apparent among the different cohorts (Table 1). The first cohort (Instars I and II) was significantly less abundant in the core of the CIL (Stratum I) than in the S2, D1 and D2 strata (leastsquare means, sequential Bonferroni test). The second cohort (Instars III and IV) followed the same distribution pattern, but no significant difference in density was detected among strata. Instars V and VI were the only juveniles found in the deepest stratum (D3). Their peak density in the deep strata also shifted upwards, from D2 to D1, relative to that of the first 2 cohorts. Density was significantly different among strata only 
Table 1. Chionoecetes opilio. One-way ANOVAs comparing abundance of juvenile snow crabs (ind. $1000 \mathrm{~m}^{-2} \pm \mathrm{SE}$ ) in different temperature-depth strata, May 2001. Data were $\log _{10}(x+1)$-transformed for analysis. Crabs from the surface (S1) and the very deep (D3) layers were excluded from the analyses on Instars I to VI to meet assumptions of homoscedasticity. Significant p-values are in bold. Dissimilar superscripts indicate significant differences in crab abundance between depth strata. First- and secondhighest mean density for each instar are shaded in dark and pale grey, respectively. $\mathrm{S} 1:>1{ }^{\circ} \mathrm{C},<18 \mathrm{~m}$ deep; $\mathrm{S} 2: 0$ to $1{ }^{\circ} \mathrm{C}, 18$ to $27 \mathrm{~m}$; I: $<0^{\circ} \mathrm{C}, 27$ to $85 \mathrm{~m}$; D1: 0 to $1^{\circ} \mathrm{C}, 85$ to $105 \mathrm{~m}$; D2: 1 to $2^{\circ} \mathrm{C}, 105$ to $120 \mathrm{~m}$; D3: $>2^{\circ} \mathrm{C},>120 \mathrm{~m}$ (where $\mathrm{I}=$ core of cold intermediate layer)

\begin{tabular}{|c|c|c|c|c|c|c|c|}
\hline \multirow{2}{*}{ Stratum } & \multirow[t]{2}{*}{$\mathrm{n}$} & \multicolumn{6}{|c|}{-Instars } \\
\hline & & I-II & III-IV & $\mathrm{V}$ & VI & VII & VIII \\
\hline S1 & 9 & $3.5 \pm 2.9$ & $2.1 \pm 2.1$ & 0 & $0.3 \pm 0.3$ & $4.2 \pm 4.2^{\mathrm{a}}$ & $45.3 \pm 45.3^{a}$ \\
\hline $\mathrm{S} 2$ & 6 & $48.0 \pm 24.3^{\mathrm{a}}$ & $38.8 \pm 19.6$ & $11.4 \pm 6.4$ & $181.1 \pm 130.1^{\mathrm{a}}$ & $47.3 \pm 25.1^{\mathrm{b}}$ & $72.5 \pm 35.2^{b}$ \\
\hline I & 5 & $1.5 \pm 1.5^{\mathrm{b}}$ & $1.9 \pm 0.9$ & $1.9 \pm 1.9$ & $0.9 \pm 0.9^{b}$ & $0.5 \pm 0.5^{\mathrm{ab}}$ & $4.2 \pm 2.6^{\mathrm{ab}}$ \\
\hline D1 & 7 & $19.3 \pm 4.4^{\mathrm{a}}$ & $8.3 \pm 3.1$ & $4.1 \pm 1.3$ & $10.4 \pm 3.6^{\mathrm{ab}}$ & $4.7 \pm 2.4^{\mathrm{ab}}$ & $1.0 \pm 0.5^{\mathrm{a}}$ \\
\hline D2 & 10 & $54.8 \pm 16.7^{a}$ & $21.4 \pm 5.4$ & $2.4 \pm 1.6$ & $1.5 \pm 0.7^{b}$ & $0.9 \pm 0.7^{\mathrm{a}}$ & $0.7 \pm 0.4^{\mathrm{a}}$ \\
\hline D3 & 5 & 0 & 0 & $0.4 \pm 0.4$ & $0.2 \pm 0.2$ & $0^{\mathrm{a}}$ & $0^{\mathrm{a}}$ \\
\hline F & & 3.7 & 1.0 & 1.5 & 5.0 & 3.3 & 4.5 \\
\hline $\mathrm{p}$ & & 0.026 & 0.398 & 0.234 & 0.008 & 0.014 & 0.003 \\
\hline
\end{tabular}
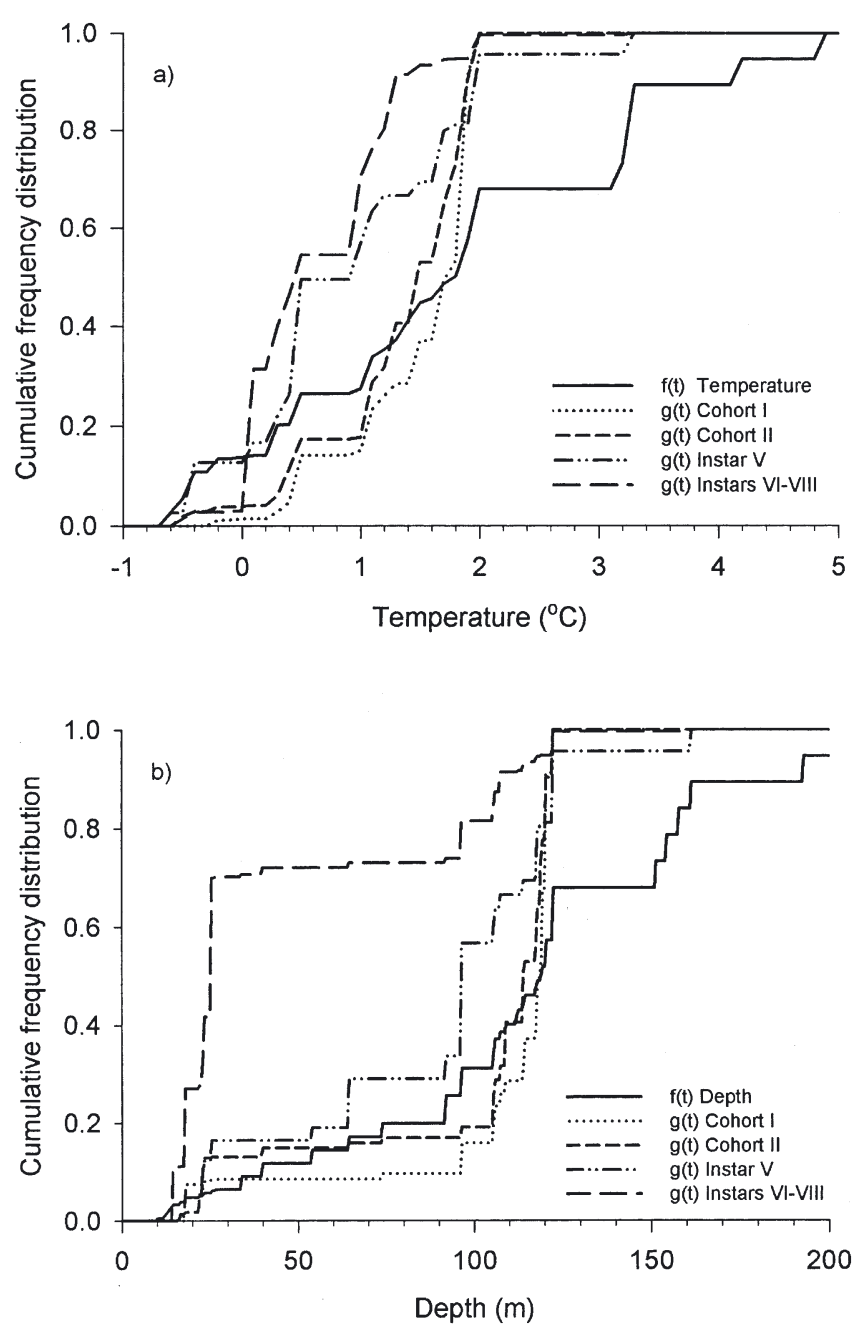

Fig. 5. Cumulative frequency distributions of abiotic factors, $\mathrm{f}(\mathrm{t})$, temperature (a) and depth (b), and of density of juvenile snow crabs Chionoecetes opilio, $\mathrm{g}(\mathrm{t})$, in May 2001 trawl survey in Baie Sainte-Marguerite ( $\mathrm{n}=45$ trawlsets). Cohort I: Instars I and II; Cohort II: Instars III and IV for Instar VI, which occurred at greater densities in the S2 stratum than in the I and D2 strata. Older juveniles of Instars VII and VIII were scarce in the D2 stratum, absent from the D3 stratum, and occurred at increasingly high densities in the 2 surface strata. Instar VII had a significantly higher density in the S2 stratum than in the S1, D2 and D3 strata. Instar VIII occurred at a significantly higher density in the S2 stratum than in the S1, D1, D2 and D3 strata.

In the cumulative distribution function (CDF) analysis relative to temperature (Fig. 5a), the CDFs of Cohorts I and II departed moderately from the temperature CDF ( $p=0.088$ and $p=0.149$, respectively), as more than $95 \%$ of those juveniles concentrated between 0.3 and $2.0^{\circ} \mathrm{C}$, which represented approximately $45 \%$ of the available temperatures. However, Instar $\mathrm{V}$ was distributed proportionately to the available temperatures $(p=0.400)$. The CDF of combined Instars VI to VIII was moderately different from that of the temperature CDF ( $p=0.130$ ) with about $90 \%$ of all individuals associated with temperatures between 0 and $1.3^{\circ} \mathrm{C}$. Overall, juveniles never occurred on bottoms warmer than $3.3^{\circ} \mathrm{C}$.

In the cumulative distribution function analysis relative to depth, there was a clear shift of the centre of distribution from deep to shallow bottoms with increasing crab age. In 2001, the CDFs of Cohorts I and II were moderately different from the depth CDF ( $p=0.101$ and $p=0.176$, respectively), with about $85 \%$ or more of the individuals concentrated between 95 and $120 \mathrm{~m}$, which represented $<30 \%$ of the available depths (Fig. 5b). The distribution of Instar V crabs was not different from that of the available depths ( $p=0.453)$. The CDF of combined Instars VI to VIII differed from the depth CDF ( $p=0.051$ ), with approximately $70 \%$ of individuals concentrated above $26 \mathrm{~m}$, which represented $6 \%$ of the available bottom area. 


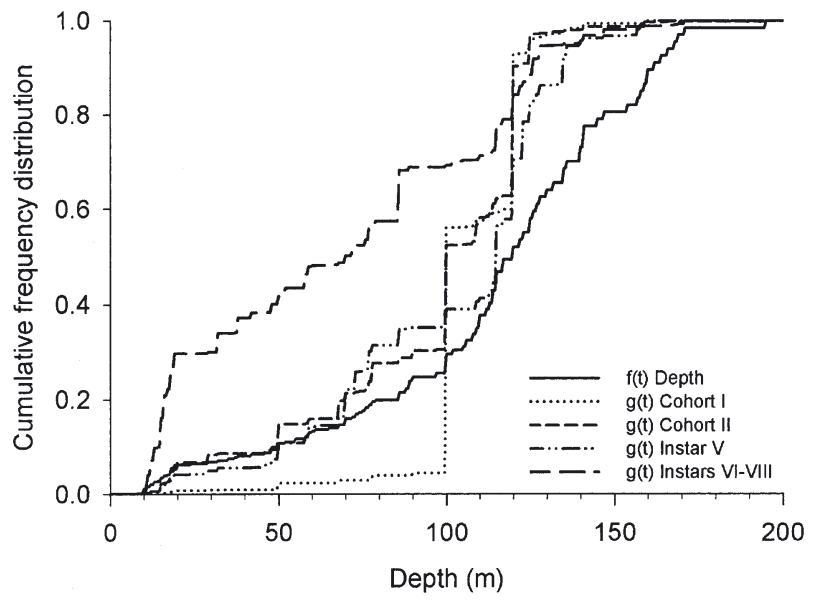

Fig. 6. Cumulative frequency distributions of depth, $f(t)$, and of abundance of juvenile snow crabs Chionoecetes opilio, $\mathrm{g}(\mathrm{t})$, from 1989 to 2000 spring trawl surveys in Baie SainteMarguerite ( $\mathrm{n}=138$ trawlsets). Cohort I: Instars I and II; Cohort II: Instars III and IV

Analysis of the 1989 to 2000 data revealed a similar, although less contrasted, depth-distribution pattern of juveniles (Fig. 6). The CDF of Cohort I was not different from the depth CDF $(p=0.795)$, but numbers of individuals were very small due to poor trawl efficiency for these crab sizes. The CDFs of Cohort II and of Instar V differed from the depth CDF ( $p=0.042$ and $p=0.057$, respectively), as about 60 to $65 \%$ of the individuals were concentrated between 100 and $125 \mathrm{~m}$. The CDF of Instars VI to VIII was significantly different from that of available depths $(p<0.001)$, with approximately $70 \%$ of the individuals distributed between 10 and $85 \mathrm{~m}$, which represented $<25 \%$ of the available bottom area. Overall, no juvenile occurred deeper than $175 \mathrm{~m}$ over the 1989 to 2001 period.

All sediment samples had a high content of mud $\left(<63 \mu \mathrm{m}_{i}, 11\right.$ to $74 \%$ ) or sand ( $63 \mu \mathrm{m}$ to $2 \mathrm{~mm}, 25$ to $98 \%$; detailed results in Dionne 2002). Gravel (>2 mm) was either absent or accounted for a maximum of $12 \%$ of total sediment weight. Given that sediment grainsize was rather uniform across the sampled area of Baie Sainte-Marguerite, no relationship between crab density and sediment type could be established.

\section{Laboratory experiments}

No gregarious behaviour was observed at the small spatial scale of our experiments. The distribution of juveniles was either uniform for Instar II $(R=1.26$ to $1.46, \mathrm{p}<0.05)$, or random for Instar $\mathrm{V}(\mathrm{R}=1.14$ to 1.25 , $\mathrm{p}>0.05$ ).

Temperature and substratum preferences varied among instars. When placed in a temperature gradient of 0 to $2.5^{\circ} \mathrm{C}$, Instar III selected temperatures of 0 to $1.5^{\circ} \mathrm{C}$ (Table 2, Fig. 7a) and concentrated in mud (Fig. 7b). Instar IV crabs had no temperature or substratum preference (Table 2, Fig. 7). Instar V selected temperatures of 1 to $2.5^{\circ} \mathrm{C}$, but no specific substratum was preferred. In the experimental range of 1.5 to $4.5^{\circ} \mathrm{C}$, Instar $\mathrm{V}$ had no temperature preference (Fig. 8a), but selected mud more than other sediments (Table 3). In the warmest thermal gradient, from 3 to $5.5^{\circ} \mathrm{C}$, a preference for temperatures of 3 to $4.5^{\circ} \mathrm{C}$ (Fig. 8b) was observed but no specific substratum choice was noted (Table 3). On mud, most individuals of Instars III, IV and V were buried, with only their eyes and rostrum emerged from the sediment.

\section{DISCUSSION}

The distribution patterns of juvenile snow crabs in the field as well as temperature and substratum preferences under controlled laboratory conditions were examined. Juvenile snow crabs had an heterogeneous distribution among the temperature-depth strata and expressed specific habitat preferences, both ontogeny-dependent. Below, we first discuss the main abiotic factors which govern juvenile distribution, then

Table 2. Chionoecetes opilio. Two-factor ANOVAs comparing abundance of juveniles in different temperature (cold, medium, warm; from 0 to $2.5^{\circ} \mathrm{C}$ ) and substratum (mud, sand, gravel) sections. Replicate is random factor; temperature and substratum are fixed factors. Significant $p$ values are in bold. Transformations are written beside each analysis

\begin{tabular}{|lrccc|}
\hline Source & df & MS & $F$ & $\mathrm{p}$ \\
\hline Instar III (raw) & & & & \\
$\quad$ Replicate $(\mathrm{R})$ & 2 & 1.56 & 0.93 & 0.466 \\
Temperature $(\mathrm{T})$ & 2 & 1.56 & 7.79 & $\mathbf{0 . 0 4 2}$ \\
Error $a(\mathrm{R} \times \mathrm{T})$ & 4 & 1.52 & 1.02 & 0.434 \\
Substratum $(\mathrm{S})$ & 2 & 1.52 & 12.81 & $\mathbf{0 . 0 0 1}$ \\
$\mathrm{T} \times \mathrm{S}$ & 4 & 1.52 & 3.00 & 0.063 \\
Error $b(\mathrm{R} \times \mathrm{S}+\mathrm{R} \times \mathrm{T} \times \mathrm{S})$ & 12 & 1.52 & & \\
Instar IV $\left(\log _{10}(x+1)\right)$ & & & & \\
$\quad$ Replicate & 2 & 0.04 & 0.08 & 0.926 \\
Temperature & 2 & 0.04 & 1.88 & 0.266 \\
Error $a(\mathrm{R} \times \mathrm{T})$ & 4 & 0.05 & 0.82 & 0.540 \\
Substratum & 2 & 0.05 & 0.47 & 0.635 \\
$\mathrm{~T} \times \mathrm{S}$ & 4 & 0.05 & 2.37 & 0.111 \\
Error $b(\mathrm{R} \times \mathrm{S}+\mathrm{R} \times \mathrm{T} \times \mathrm{S})$ & 12 & 0.05 & & \\
Instar V $\left(\log { }_{10}(x+1)\right)$ & & & & \\
Replicate & & & & \\
Temperature & 7 & 0.10 & 0.12 & 0.996 \\
Error $a(\mathrm{R} \times \mathrm{T})$ & 2 & 0.10 & 5.46 & $\mathbf{0 . 0 1 8}$ \\
Substratum & 14 & 0.06 & 1.82 & 0.068 \\
$\mathrm{~T} \times \mathrm{S}$ & 2 & 0.06 & 1.92 & 0.160 \\
Error $b(\mathrm{R} \times \mathrm{S}+\mathrm{R} \times \mathrm{T} \times \mathrm{S})$ & 42 & 0.06 & 0.66 & 0.625 \\
& & & \\
\hline
\end{tabular}



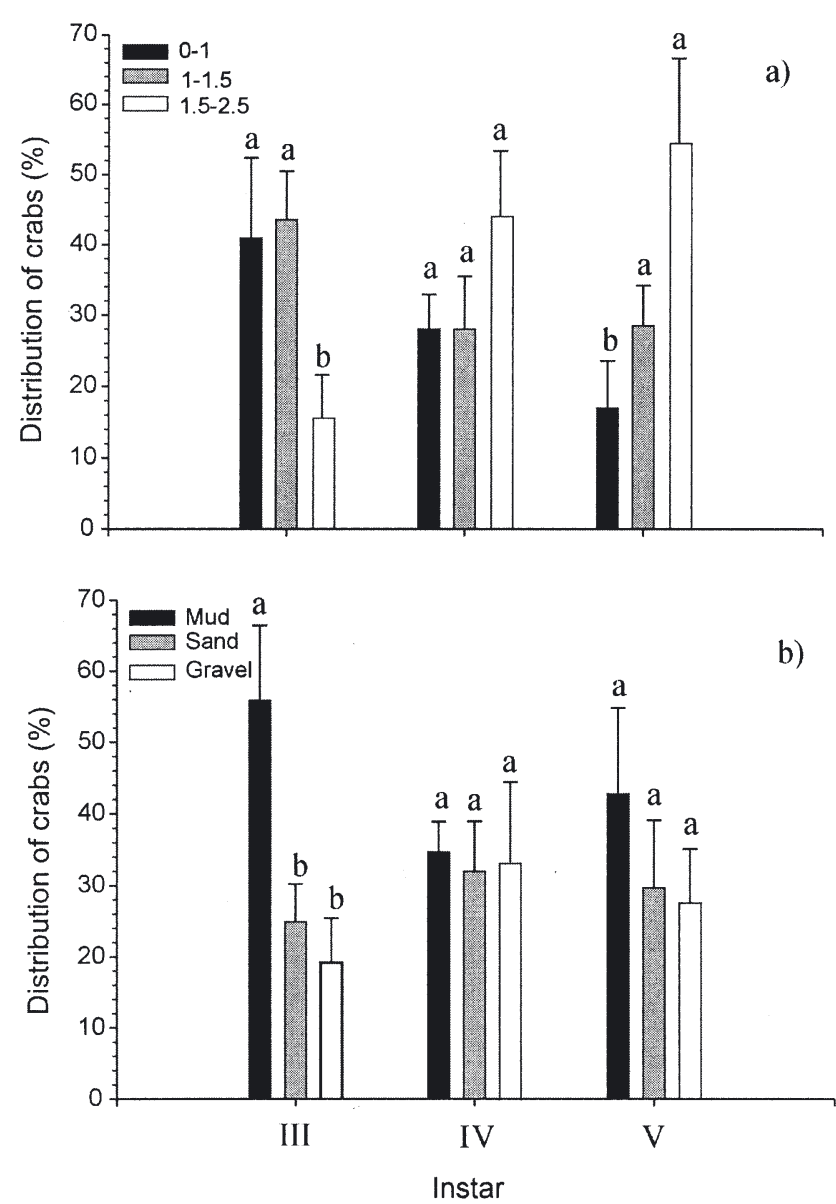

Fig. 7. Chionoecetes opilio. Distribution of juveniles among (a) different temperature zones $\left({ }^{\circ} \mathrm{C}\right.$ ) and (b) different types of substratum in a controlled laboratory experiment. Standard error bars with dissimilar letters differ significantly from each other

we consider the likely causes of the differences in distribution and habitat preferences among juvenile instars.

\section{Abiotic factors influencing juvenile distribution}

Temperature seemed to be more important than substratum for determining the spatial distribution of juvenile snow crabs in the field and under the current experimental conditions. In particular, the bimodal density pattern of Cohorts I and II in Baie SainteMarguerite cannot be explained by substratum because sandy-mud occurred throughout the study area. However, the 3 strata most densely populated by the first 2 cohorts were the only ones that would be expected to offer a 0 to $1.5^{\circ} \mathrm{C}$ temperature range (Gilbert \& Pettigrew 1997) almost year-round (D1 and D2) or for a period of several months (S2). This is the
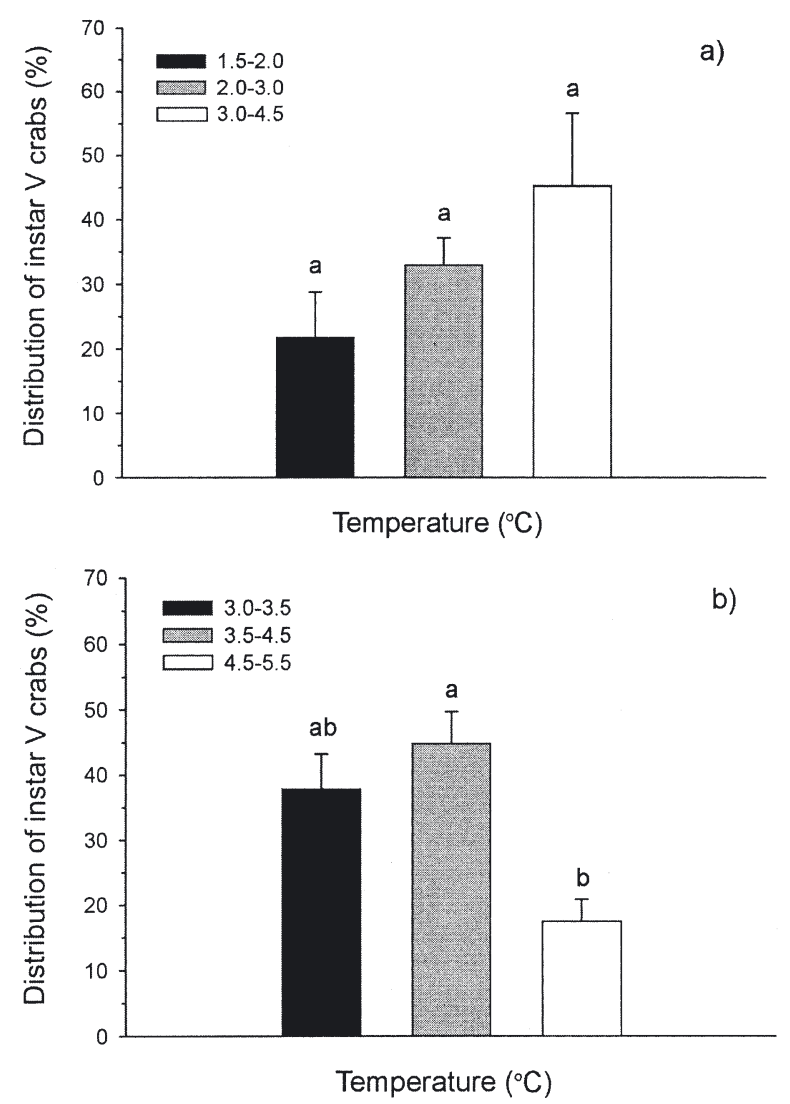

Fig. 8. Chionoecetes opilio. Distribution of Instar V juveniles among different temperature zones in a controlled laboratory experiment: thermal gradient of (a) 1.5 to $4.5^{\circ} \mathrm{C}$ and (b) 3.0 to $5.5^{\circ} \mathrm{C}$. Standard error bars with dissimilar letters differ significantly from each other

Table 3. Chionoecetes opilio. Two-factor ANOVAs comparing abundance of Instar $\mathrm{V}$ in different temperature (cold, medium, warm) and substratum (mud, sand, gravel) sections. Replicate is random factor; temperature and substratum are fixed factors. Significant p-values are in bold. Transformations are written beside each analysis. Modified Gradient I = 1.5 to $4.5^{\circ} \mathrm{C}$; Modified Gradient II $=3$ to $5.5^{\circ} \mathrm{C}$

\begin{tabular}{|c|c|c|c|c|}
\hline Source & df & MS & $F$ & $\mathrm{p}$ \\
\hline \multicolumn{5}{|l|}{ Modified gradient I $\left(\log _{10}(x+1)\right)$} \\
\hline Replicate & 2 & 0.02 & 0.35 & 0.724 \\
\hline Temperature & 2 & 0.15 & 3.51 & 0.132 \\
\hline Error $a(\mathrm{R} \times \mathrm{T})$ & 4 & 0.04 & 1.42 & 0.288 \\
\hline Substratum & 2 & 0.19 & 6.28 & 0.014 \\
\hline $\mathrm{T} \times \mathrm{S}$ & 4 & 0.02 & 0.61 & 0.666 \\
\hline Error $b(\mathrm{R} \times \mathrm{S}+\mathrm{R} \times \mathrm{T} \times \mathrm{S})$ & 12 & 0.03 & & \\
\hline \multicolumn{5}{|l|}{ Modified Gradient II (raw) } \\
\hline Replicate & 2 & 0.56 & 0.20 & 0.826 \\
\hline Temperature & 2 & 0.56 & 19.40 & 0.009 \\
\hline Error $a(\mathrm{R} \times \mathrm{T})$ & 4 & 1.57 & 0.35 & 0.837 \\
\hline Substratum & 2 & 1.57 & 1.13 & 0.355 \\
\hline $\mathrm{T} \times \mathrm{S}$ & 4 & 1.57 & 0.99 & 0.451 \\
\hline Error $b(\mathrm{R} \times \mathrm{S}+\mathrm{R} \times \mathrm{T} \times \mathrm{S})$ & 12 & 1.57 & & \\
\hline
\end{tabular}


temperature range preferred by the smallest instar in the laboratory experiments. Considering the large vertical and horizontal distances separating the 2 areas of concentration of crabs from Cohorts I and II, the bimodal pattern seems also inconsistent with a specific depth, light or salinity requirement. Brêthes et al. (1987) performed partial correlation analysis on the density of juveniles of $<30 \mathrm{~mm} \mathrm{CW}$ and various abiotic factors, and they also suggested that temperature was more important than substratum and depth for determining juvenile distribution patterns.

Contrary to our initial hypothesis and to the interpretations of Slizkin (1982) and Lovrich et al. (1995), early juvenile snow crabs were scarce in the core of the CIL and did not associate with the coldest water available $\left(<0^{\circ} \mathrm{C}\right)$. Our study is the first to evaluate the distribution of early juvenile snow crabs in very cold water and to test habitat preferences in the laboratory. Previous studies were conducted in the field, and they either did not assess bottom temperature specifically (Slizkin 1982, Lovrich et al. 1995), or they were conducted in warmer climatological periods (Brêthes et al. 1987) when subzero temperatures were non-existent (Gilbert \& Pettigrew 1997).

The association of early juveniles with a narrow range of temperatures above $0^{\circ} \mathrm{C}$ may be advantageous. Indeed, Instars II to VI have a greater scope for growth and survive better at 0 and $1.5^{\circ} \mathrm{C}$ than at -1.2 and $3^{\circ} \mathrm{C}$ (Gravel 2002). Some authors have suggested that temperatures $<0^{\circ} \mathrm{C}$ are detrimental to reptant decapod crustaceans, including unspecified Chionoecetes species, because these have a reduced ability to regulate $\left[\mathrm{Mg}^{2+}\right]$ in the haemolymph (Frederich et al. 2000). This component acts as an anaesthetic at temperatures $<0^{\circ} \mathrm{C}$, and could reduce the scope of activity of crabs, increase their vulnerability to predation, and ultimately explain why they have not been successful at colonizing the coldest polar and subpolar regions (Frederich et al. 2001). However, assuming that the Cohort I snow crabs found in the S2 stratum settled there as megalopae, which is reasonable considering their cryptic behavior and limited mobility (Lovrich et al. 1995), then some early juveniles must be able to tolerate the temperatures of -1 to $-1.5^{\circ} \mathrm{C}$ that prevail in surface waters for a few months during winter (Koutitonsky \& Bugden 1991). Also, the vertical temperature profile was warmer and subzero temperatures were lacking in late August 2000, when snow crab megalopae presumably began to settle. Thus, if the bimodal distribution pattern observed for Cohort I crabs in spring 2001 is representative of the settlement pattern, it suggests that megalopae have slightly warmer temperature preferenda than early benthic juveniles. Research on snow crab megalopae behaviour and settlement is necessary to assess this hypothesis.
In the laboratory, Instars III and V had a preference for mud but only within their preferred temperature range, further suggesting that temperature is the primary factor influencing distribution and that substratum might play a secondary role in the smaller scale distribution. The observed burrowing behaviour in mud might serve to reduce predation, as suggested by Stevens et al. (1994) for tanner crabs Chionoecetes bairdi. This burrowing behaviour was also observed for juvenile snow crabs in the field (Conan et al. 1996) and for other species of crabs (Richards 1992, Zhou \& Shirley 1998).

Although we did not specifically consider dissolved oxygen in this study, one of our preliminary experiments suggests that it may be an important factor regulating distribution of early juvenile snow crabs. Oxygen saturation decreases with increasing depth in the northern Gulf of St. Lawrence, and the $69 \%$ oxygen saturation threshold which induces anomalous behaviour in Instar $\mathrm{V}$ snow crabs is reached at about 110 to $120 \mathrm{~m}$ of depth (Fig. 9). This is consistent with the sharp reduction in juvenile density at a depth of $120 \mathrm{~m}$ in Baie Sainte-Marguerite, both in the present study and in the 1989 to 2000 record. Interestingly, juvenile blue crab Callinectes sapidus mortality over 1 mo reaches $50 \%$ at $69 \%$ oxygen saturation (Das \& Stickle 1993). Blue crab megalopae are much more tolerant of hypoxia than early juveniles, but when exposed to hypoxic conditions they delay metamorphosis and may actively search for more oxygenated habitats (Tankersley \& Wieber 2000). Moreover, tolerance to hypoxia

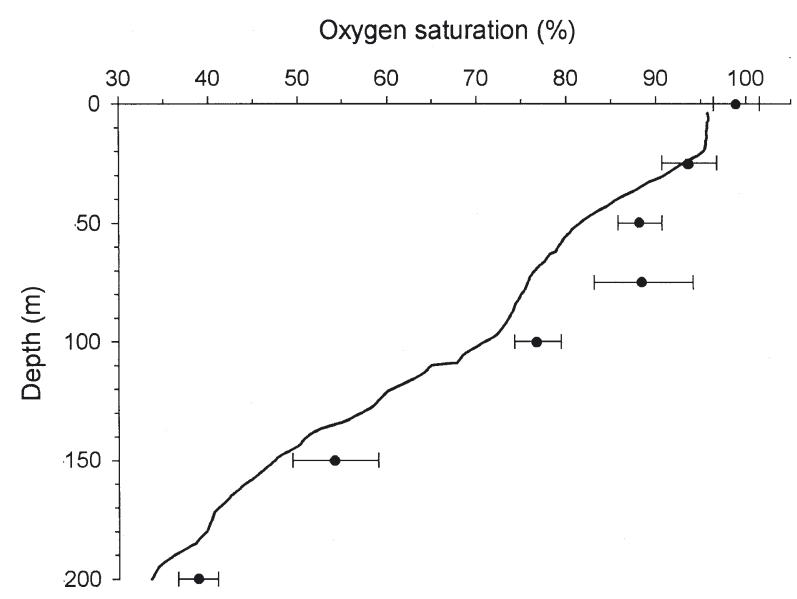

Fig. 9. Mean oxygen-saturation profile as a function of depth in Baie Sainte-Marguerite. Continuous line represents mean profile for December 2001 ( $n=2$ casts). Samples were taken every $1 \mathrm{~m}$ using a SBE-43 oxygen sensor from Seabird Electronics. $(\bullet)$ Mean \pm SE climatologic profile (1961 to 2002; different months; $\mathrm{n}=4$ to 11 samples/depth) based on Winkler titrations using Niskin bottles 
increases with increasing size in blue crabs (Das \& Stickle 1993), as in many other taxa (Diaz \& Rosenberg 1995). If this is true for snow crabs also, then this feature and the greater tolerance of large snow crabs to warmer temperature (Foyle et al. 1989) could explain why large males can occur at much greater depths than juveniles and mature females (Coulombe et al. 1985, Lovrich et al. 1995).

\section{Changes in distribution with ontogeny}

A shift in juvenile distribution towards shallower depths with increasing age was also observed between 1989 and 2000, confirming that 2001 was not an exceptional year. However, the historical trends were not as pronounced as those of 2001, which could be due to the pooling of years with slightly different temperaturedepth profiles (Gilbert \& Pettigrew 1997). The ontogenic shift in juvenile distribution may reflect either high mortality in deep strata or migration to shallow waters. Several direct and indirect clues support the latter hypothesis: (1) slightly warmer water became preferred and the degree of stenothermia was reduced between Instars III and $\mathrm{V}$ in the current laboratory study; (2) movement/dispersion during Instars V and VI is suggested by greater densities in the D1 than in the D2 layers and by the appearance of juvenile crabs in the D3 layer in the present study; (3) the enzymes for aerobic muscle activity are expressed from Instar VI (Angers et al. 1994) onwards, and this may allow rapid and sustained movements by crabs adjusting their vertical position to sudden temperature variations; (4) there was a trend towards stable or increasing juvenile densities by cohort at shallow depths in Baie SainteMarguerite, which suggests immigration (B.S.-M. unpubl. data).

Habitat shifts with ontogeny are common among mobile marine animals. It has been suggested that mobile animals may select habitats so that the ratio of mortality risk $(\mu)$ over growth rate $(g)$ is minimised, with both terms being important for choice of optimal habitat (Dahlgren \& Eggleston 2000). In the case of snow crabs, warmer surface temperatures could increase growth for older juvenile stages, as documented in other species of crabs (Brown et al. 1992, Hartnoll \& Bryant 2001). Migration towards deeper waters for access to warm water is not a viable option for juvenile snow crabs, considering the severity of hypoxia at depth in the NW Gulf of St. Lawrence (Fig. 9). Predation risk may also influence the emigration of juvenile crabs away from deeper water (e.g. Hines et al. 1987), while predator-related mortality could contribute directly to the observed shift in the centre of distribution. Cod, for example, is a predator of snow crabs (Robichaud et al. 1991) and it inhabits depths between 90 and 400 m (Castonguay et al. 1999). Cannibalism on Instars V to VII by larger snow crabs, which concentrate in deeper waters (Lovrich et al. 1995), can also be very important (Dutil et al. 1997, Lovrich \& Sainte-Marie 1997).

In summary, water temperature plays a central role in the distribution of juvenile snow crabs and in their habitat selection. Our experiments support the hypothesis that juvenile snow crabs make active choices based on water temperature and substratum. Oxygen may also be a limiting factor, but more research is needed to confirm this. Future studies should examine habitat selection by snow crab megalopae to determine whether it matches the preferences observed for Cohort I juveniles in the present study and for megalopae in our preliminary experiments (Dionne 2002). It would also be interesting to study the ontogenic change in temperature preferences of juveniles from a physiological point of view. Instars I to III appear to prefer colder water and to be more stenothermic than older juvenile instars. There is possibly a migration of Instar V to VII juveniles to shallow waters, but this hypothesis and the underlying causes need to be studied in more detail. The ideal habitat of the earliest benthic stages can tentatively be defined as fine sediment bottoms in waters of 0 to $2^{\circ} \mathrm{C}$ with oxygen saturation in excess of $69 \%$. Early benthic stages may represent the weakest link in the snow crab life cycle considering their narrow habitat requirements and their reduced mobility. Early juveniles may also represent the population component that mostly limits the geographic range of snow crab distribution.

Acknowledgements. Support for this research was provided by the Department of Fisheries and Oceans Strategic Science Fund, the Impacts and Adaptation component of Canada's Climate Change Action Fund (CCAF), the Groupe Interuniversitaire de Recherches Océanographiques du Québec (GIROQ), the Département de Biologie, Université Laval, and a scholarship to M.D. from the Fonds pour la Formation de Chercheurs et l'Aide à la Recherche (FCAR). Special thanks to L. Lapointe (GIROQ) and G. Daigle (Département de Mathématiques et Statistiques) for their statistical help. We also thank C. Turcotte, B. Chénard, J. P. Allard, R. Larocque and I. Bérubé (Fisheries and Oceans Canada) for their help in the field and in the laboratory.

\section{LITERATURE CITED}

Alunno-Bruscia M, Sainte-Marie B (1998) Abdomen allometry, ovary development, and growth of female snow crab Chionoecetes opilio in the Gulf of Saint Lawrence (Brachyura, Majidae). Can J Fish Aquat Sci 55:459-477 Angers A, Pothier F, Sévigny JM, Sainte-Marie B (1994) Tissue specificity and ontogeny of lactate dehydrogenase in snow crab, Chionoecetes opilio (Brachyura, Majidae). 
Comp Biochem Physiol B 108:385-395

Boudreau B, Bourget E, Simard Y (1990) Benthic invertebrate larval response to substrate characteristics at settlement: shelter preferences of the American lobster Homarus americanus. Mar Biol 106:191-198

Brêthes JCF, Coulombe F, Lafleur PE, Bouchard R (1987) Habitat and spatial distribution of early benthic stages of the snow crab Chionoecetes opilio O. Fabricius off the north shore of the Gulf of St. Lawrence. J Crustac Biol 7: $667-681$

Brown SD, Bert TM, Tweedale WA, Torres JJ, Lindberg WJ (1992) The effects of temperature and salinity on survival and development of early life stage Florida stone crabs Menippe mercenaria (Say). J Exp Mar Biol Ecol 157: 115-136

Castonguay M, Rollet C, Fréchet A, Gagnon P, Gilbert D, Brêthes JC (1999) Distribution changes of Atlantic cod (Gadus morhua L.) in the northern Gulf of St. Lawrence in relation to an oceanic cooling. ICES J Mar Sci 56:333-344

Clark PJ, Evans FC (1954) Distance to nearest neighbor as a measure of spatial relationships in populations. Ecology 35:445-453

Conan GY, Starr M, Comeau M, Therriault JC, Robichand G, Hernàndez FXM (1996) Life history strategies, recruitment fluctuations, and management of the Bonne Bay Fjord Atlantic snow crab (Chionoecetes opilio). In: Proc Int Symp Biology, Management and Economics of Crabs from High Latitude Habitats, October 1995, Anchorage, Alaska. Lowell Wakefield Fish Symp Ser, Alsk Sea Grant College Prog Rep No. 96-02, University of Alaska Fairbanks, Fairbanks, AK, p 59-97

Coulombe F, Brêthes JCF, Bouchard R, Desrosiers G (1985) Ségrégation édaphique et bathymétrique chez le crabe des neiges, Chionoecetes opilio (O. Fabr.), dans le sud-ouest du golfe du Saint-Laurent. Can J Fish Aquat Sci 42:169-180

Cronin TW (1986) Photoreception in marine invertebrates. Am Zool 26:403-415

Dahlgren CP, Eggleston DB (2000) Ecological processes underlying ontogenic habitat shifts in a coral reef fish. Ecology 81:2227-2240

Das T, Stickle WB (1993) Detection and avoidance of hypoxic water by juvenile Callinectes sapidus and C. similis. Mar Biol 120:593-600

Diaz RJ, Rosenberg R (1995) Marine benthic hypoxia: a review of its ecological effects and the behavioural responses of benthic macrofauna. Oceanogr Mar Biol Annu Rev 33: 245-303

Dionne M (2002) Distribution et sélection de l'habitat chez les mégalopes et les juvéniles du crabe des neiges, Chionoecetes opilio, dans un contexte de changement climatique. MSc thesis, Université Laval, Québec

Drinkwater KF (1996) Atmospheric and oceanic variability in the northwest Atlantic during the 1980s and early 1990s. J Northwest Atl Fish Sci 18:77-97

Dutil JD, Munro J, Péloquin M (1997) Laboratory study of the influence of prey size on vulnerability to cannibalism in snow crab (Chionoecetes opilio O. Fabricius, 1780). J Exp Mar Biol Ecol 212:81-94

Foyle TP, O'Dor RK, Elner RW (1989) Energetically defining the thermal limits of the snow crab. J Exp Biol 145:371-393

Frank KT, Perry RI, Drinkwater KF (1990) Predicted response of northwest Atlantic invertebrate and fish stocks to $\mathrm{CO}_{2}$-induced climate change. Trans Am Fish Soc 119: 353-365

Frederich M, Sartoris FJ, Arntz WE, Pörtner HO (2000) Haemolymph $\mathrm{Mg}^{2+}$ regulation in decapod crustaceans: physiological correlates and ecological consequences in polar areas. J Exp Biol 203:1383-1393

Frederich M, Sartoris FJ, Pörtner HO (2001) Distribution patterns of decapod crustaceans in polar areas: a result of magnesium regulation? Polar Biol 24:719-723

Gilbert D, Pettigrew B (1997) Interannual variability (1948-1994) of the CIL core temperature in the Gulf of St. Lawrence. Can J Fish Aquat Sci 54(Suppl 1):57-67

Gosselin LA, Qian PY (1997) Juvenile mortality in benthic marine invertebrates. Mar Ecol Prog Ser 146:265-282

Gravel K (2002) Bilan énergétique des juvéniles du crabes des neiges, Chionoecetes opilio, à differentes températures. MSc thesis, Université du Québec à Rimouski

Hartnoll RG, Bryant AD (2001) Growth to maturity of juveniles of the spider crabs Hyas coarctatus Leach and Inachus dorsettensis (Pennant) (Brachyura: Majidae). J Exp Mar Biol Ecol 263:143-158

Hines AH, Lipcius RN, Haddon AM (1987) Population dynamics and habitat partitioning by size, sex, and molt stage of blue crabs Callinectes sapidus in a subestuary of central Chesapeake Bay. Mar Ecol Prog Ser 36:55-64

Hunt HL, Scheibling RE (1997) Role of early post-settlement mortality in recruitment of benthic marine invertebrates. Mar Ecol Prog Ser 155:269-301

Koutitonsky VG, Bugden GL (1991) The physical oceanography of the Gulf of St. Lawrence: a review with emphasis on the synoptic variability of the motion. In: Therriault JC (ed) The Gulf of St. Lawrence: small ocean or big estuary? Can Spec Publ Fish Aquat Sci 113:57-90

Lilly GR, Parsons DG, Kulka DW (2000) Was the increase in shrimp biomass on the northeast Newfoundland shelf a consequence of a release in predation pressure from cod? J Northwest Atl Fish Sci 27:45-61

Linnane A, Mazzoni D, Mercer JP (2000) A long-term mesocosm study on the settlement and survival of juvenile European lobster Homarus americanus L. in four natural substrata. J Exp Mar Biol Ecol 249:51-64

Lovrich GA, Sainte-Marie B (1997) Cannibalism in the snow crab, Chionoecetes opilio (O. Fabricius) (Brachyura: Majidae), and its potential importance to recruitment. J Exp Mar Biol Ecol 211:225-245

Lovrich GA, Sainte-Marie B, Smith BD (1995) Depth distribution and seasonal movements of Chionoecetes opilio (Brachyura: Majidae) in Baie Sainte-Marguerite, Gulf of Saint Lawrence. Can J Zool 73:1712-1726

Myers RA, Hutchings JA, Barrowman NJ (1996) Hypotheses for the decline of cod in the North Atlantic. Mar Ecol Prog Ser 138:293-308

Perry RI, Smith SJ (1994) Identifying habitat associations of marine fishes using survey data: an application to the northwest Atlantic. Can J Fish Aquat Sci 51:589-602

Rice WR (1989) Analyzing tables of statistical tests. Evolution 43:223-225

Richards RA (1992) Habitat selection and predator avoidance: ontogenic shifts in habitat use by the Jonah crab Cancer borealis (Stimpson). J Exp Mar Biol Ecol 156:187-197

Robichaud DA, Bailey RF, Elner RW (1989) Growth and distribution of snow crab, Chionoecetes opilio, in the southeastern Gulf of St. Lawrence. J Shellfish Res 8:13-23

Robichaud DA, Elner RW, Bailey RFJ (1991) Differential selection of crab Chionoecetes opilio and Hyas spp. as prey by the sympatric cod Gadus morhua and thorny skate Raja radiata. US Natl Mar Fish Serv 89:669-680

Rosenkranz GE, Tyler AV, Kruse GH (2001) Effects of water temperature and wind on year-class success of tanner crabs in Bristol Bay, Alaska. Fish Oceanogr 10:1-12

Sainte-Marie B (1997) Comment — an improved link between industry, management and science: review of case history 
of the southwestern Gulf of St. Lawrence snow crab fishery. Can J Fish Aquat Sci 54:496-500

Sainte-Marie B, Hazel F (1992) Moulting and mating of snow crabs, Chionoecetes opilio (O. Fabricius), in shallow waters of the northwestern Gulf of Saint Lawrence. Can J Fish Aquat Sci 49:1282-1293

Sainte-Marie B, Raymond S, Brêthes JC (1995) Growth and maturation of the benthic stages of male snow crab, Chionoecetes opilio (Brachyura: Majidae). Can J Fish Aquat Sci 52:903-924

Slizkin AG (1982) Distribution of snow crabs of the genus Chionoecetes and their habitat in the northern part of the Pacific Ocean: population dynamics and reproductive conditions of commercial invertebrates and algae in the Far Eastern Seas. Izv Tikhookean Nauchno-Issled Inst Ryb Khoz Oceanogr 106:26-33 (Can Transl Fish Aquat Sci No. 5664)

Stevens BG (2003) Settlement, substratum preference, and

Editorial responsibility: Gareth Harding (Contributing Editor), Dartmouth, Nova Scotia, Canada survival of red king crab Paralithodes camtschaticus (Tilesius, 1815) glaucothoe on natural substrata in the laboratory. J Exp Mar Biol Ecol 283:63-78

Stevens BG, Haaga JA, Donaldson WE (1994) Aggregative mating of tanner crabs, Chionoecetes bairdi. Can J Fish Aquat Sci 51:1273-1280

Tankersley RA, Wieber MG (2000) Physiological responses of postlarval and juvenile blue crabs Callinecetes sapidus to hypoxia and anoxia. Mar Ecol Prog Ser 194:179-191

Tremblay MJ (1997) Snow crab (Chionoecetes opilio) distribution limits and abundance trends on the Scotian Shelf. J Northwest Atl Fish Sci 21:7-22

Worm B, Myers RA (2003) Meta-analysis of cod-shrimp interactions reveals top-down control in oceanic food webs. Ecology 84:162-173

Zhou S, Shirley TC (1998) A submersible study of red king crab and tanner crab distribution by habitat and depth. J Shellfish Res 17:1477-1479

Submitted: October 10, 2002; Accepted: May 2, 2003 Proofs received from author(s): August 29, 2003 